\title{
O hranicích a mnohosti Jiných Relační perspektiva studia subkultur
}

Martin Heřmanský - Hedvika Novotná

\author{
DOI: 10.21104/CL.2019.1.01 \\ On Boundaries and Multiple 'Others': A Relational Perspective in \\ Studying Subcultures
}

\begin{abstract}
Despite drawing on a large body of different paradigms, subcultural studies have been conceptualizing subcultures rather uniformly as a world in itself, a reaction to dominant society or a combination of both.

In our paper, we argue for more encompassing theoretical view, we call the relational perspective. Inspired by symbolic interactionism and studies on identity and alterity, while building on concepts devised in post-subcultural studies, we claim that particular subcultures are delineated in respect to many different actors. These can be roughly classified into categories of mainstream, other subcultures and enactments of one's own subculture.

Grounded in empirical research of punk and emo subcultures and employing the concepts of in/authenticity (based on subcultural capital formed by subcultural style, ideology and practice), we will show the possibility of application of this perspective in studying contemporary subcultural formations both diachronically and synchronically.
\end{abstract}

\section{Key words}

relational perspective, subcultures, subcultural identity, authenticity, punk, emo

\section{Acknowledgment}

Vznik tohoto textu byl podpořen z prostředků Institucionální podpory na dlouhodobý koncepční rozvoj výzkumné organizace (MŠMT-2018).

\section{Contact}

Mgr. Martin Heřmanský, Ph.D., Univerzita Karlova, Fakulta humanitních studií, U Kř́iže 8, 15800 Praha 5, Czech Republic; e-mail: martin. hermansky@fhs.cuni.cz.

Mgr. Hedvika Novotná, Ph.D., Univerzita Karlova, Fakulta humanitních studií, U Kř́žze 8, 15800 Praha 5, Czech Republic; e-mail: hedvika.no@) gmail.com.

\section{Jak citovat / How to cite}

Heřmanský, Martin - Novotná, Hedvika. (2019). O hranicích a mnohosti Jiných. Relační perspektiva studia subkultur. Český lid 106, 7-28. doi:http://dx.doi.org/10.21104/CL.2019.1.01 
Subkulturní studia jakožto bytostně multidisciplinární akademické pole čerpala během své historie $\mathrm{z}$ celé řady různých paradigmat. Počínajíc sociologickou tradicí chicagské školy, pokračujíc perspektivou kulturálních studií, již zaujímalo birminghamské CCCS, a postmodernismem postsubkulturních studií konče. Vedle samotného předmětu zájmu, tedy subkultur, každý z těchto různých teoretických př́stupů spojovalo přesvědčení, že jeho perspektiva je nejlepším způsobem, jak dosáhnout kýženého porozumění subkulturním světům.

Tato studie s nimi toto přesvědčení nesdílí. Ačkoliv se domníváme, že námi navrhovaný relační př́istup, který níže představujeme, může být užitečným nástrojem pro porozumění subkulturní realitě v diachronní i synchronní perspektivě, nemáme ambice tvrdit, že je nejlepš́ či dokonce jediný správný. Využitelnost každé teorie či př́stupu je odvislá od problému, který chce řešit, a terénu, v němž se daný problém nahlíží. Zda je př́stup vhodný, již musí posoudit ten či ta, kteří jej aplikují.

Relační perspektiva, tedy perspektiva zdůrazňující význam vztahů subkultur $\mathrm{s}$ dalšími aktéry, vychází z předpokladu, že subkultury jakožto součást naší sociální reality jsou tu ve více, tu v méně intenzivní interakci s mnoha velmi rozmanitými aktéry. Zároveň však subkultury musí jistým zpo̊sobem udržovat svou distinktivnost, aby se nerozplynuly v rozmanitosti současného světa období pozdní modernity.

V inspiraci symbolickým interakcionismem (Fine - Kleinman 1979; Williams 2011), konstruktivistickými teoriemi identity a alterity (Spivak 1989; Brubaker - Cooper 2000; Eriksen 2007; Bottero 2010) a postsubkulturní teorií (Thornton 1996; Muggleton - Weinzierl 2003) navrhujeme př́stup, který zmíněné skutečnosti zohledňuje a zároveň umožňuje flexibilní nahlížení konstrukce subkulturní identity s využitím konceptu (ne)autentičnosti založené na kumulaci, respektive absenci subkulturního kapitálu skrze subkulturní styl, ideologii a praktiky.

První myšlenky na formulaci tohoto př́stupu vznikly při práci na diachronně koncipované studii pojednávající vývoj vztahu české punkové a skinheadské subkultury (Novotná - Dvořák 2008; Novotná - Heřmanský 2012) a postupně se profiloval při práci na její pozdější přepracované revizi (Novotná 2013; Novotná - Heřmanský 2015). Následně jsme se jej pokusili aplikovat při synchronním výzkumu české emo subkultury, jejíž etnografický výzkum jeden z autorů od roku 2013 provádí.

V následující studii nejprve stručně načrtneme dosavadní perspektivy studia subkultur s důrazem na jejich pojetí zkoumaného předmětu ve vztahu k mainstreamu, respektive dominantní společnosti. Poté nastíníme naše inspirační zdroje, abychom následně mohli prezentovat jejich syntézu, jež vedla $\mathrm{k}$ formulaci relační perspektivy. $V$ závěru pak ukážeme aplikaci této perspektivy nejprve v diachronní a následně v synchronní perspektivě. 


\section{Subkultury a dominantní společnost - nástin klíčových přístupů subkul- turních studií}

Podle Patricka Williamse (2011) lze veškeré teoretizování o subkulturách (resp. scénách, kmenech či postsubkulturách) ${ }^{1}$ shrnout do dvou základních konceptů - marginalizace a nenormativnosti. Subkulturám je tedy na jedné straně rozuměno jako produktům aktérů, již jsou marginalizováni (jak zdůrazňovala např. Chicagská sociologická škola), na straně druhé pak jako produktům aktérů, kteří záměrně odmítají zavedené normy dominantní společnosti (z čehož vycházejí postsubkulturní studia). Nicméně, jak ukázaly práce birminghamského Centra pro současná kulturální studia, nenormativnost může často být důsledkem právě marginalizace.

Výše zmíněná dvojí konceptualizace, kterou Williams (2011) vidí jako paralelu sociálněvědních teorií struktury a jednání, ${ }^{2}$ se odráží i v rozdílném př́stupu k samotné povaze subkultur, který v rámci subkulturních studií osciluje mezi póly „subkultura jako svět sám pro sebe“ a „subkultura jako součást širší společnosti“ “. ${ }^{3}$ Nelze samozřejmě říci, že by mezi těmito př́istupy byly ostré hranice ve smyslu bud'/anebo. Spíše je přesnější tvrdit, že některé perspektivy kladou větší důraz na autonomii („,svět sám pro sebe“), zatímco jiné na kontextualitu („součást širší společnosti“).

Kořeny perspektivy akcentující první z pólů, tedy „subkulturu jako svět sám pro sebe“, lze nalézt v Chicagské sociologické škole, jejíž tzv. „lidská či urbánní ekologie" (Park - Burgess 1921; srov. Williams 2011: 19) vycházela z funkcionalistického modelu společnosti jako ekvilibria (Park 1936; srov. Williams 2011: 24), které (deviantní) subkultury svou existencí narušovaly.

1 Ačkoliv jsme si vědomi toho, že zmíněné koncepty nejsou v žádném případě synonymy, diskuse jejich rozdílů přesahuje záměr této studie. Konceptuální rozdíly však nijak zásadně neomezují aplikaci relační perspektivy, jež je cílem této studie. Detaily této dlouhé a intelektuálně zajímavé diskuse viz např. (Muggleton 1998; Bennett 1999; 2005; Blackman 2005; Hesmondhalgh 2005), přehledné shrnutí viz např. (Williams 2011).

2 Williams (2011) se domnívá, že perspektiva marginalizace nahlíží na jednání aktérů v logice struktury, zatímco perspektiva nenormativnosti v logice jednání (agency).

3 Samozřejmě jsme si vědomi jistého zjednodušení, jelikož ani Chicagská škola netvrdila, že subkultury jsou zcela odříznuté od dominantní společnosti, resp. zohledňovala, že jejich vznik je podmíněn marginalizací aktérů právě ze strany dominantní společnosti. Podobně je třeba zmínit, že ačkoliv birminghamské Centrum pro současná kulturální studia nahlíželo na subkultury jako na produkt dominantní společnosti, uznávalo, že v jejich rámci funguje jistá homologie, at již sémiotická (srov. Hebdige 1979), či etnografická (srov. Willis 1978), která je formuje do jistého uceleného systému. Nicméně pro potřeby naší práce si dovolíme jisté zjednodušení. 
Subkultury tak byly chápány jako „relativně distinktioní sociální subsystémy v rámci většího sociálního systému a kultury“ (Fischer 1975: 1323; podle Williams 2007: 574, kurziva autoři).

Perspektiva subkultur jako do značné míry autonomních světů byla v rámci americké sociologie rozpracovávána i mimo Chicagskou školu. Významným př́spěvkem upevňujícím tuto perspektivu byl koncept referenčních rámců (frames of reference) Alberta Cohena (Cohen 1997). Referenčním rámcem Cohen označoval koherentní systém významů, respektive „soubor hodnot, které jedinec uznává a které odmítá, stejně jako způsobů, jak dosáhnout určitých cílů a překonat překážky, s nimiž se setkává" (Smolík 2010: 33), tedy soubor hodnot a způsobů, které si jedinci v rámci subkultury osvojují jako nástroj vyrovnání se s marginalizací dominantní společnosti.

V současnosti lze důraz na tuto perspektivu nalézt např́klad v práci Paula Hodkinsona (2002), který zdůrazňuje, že subkultury, ,ačkoliv nevyhnutelně spojeny se společností a politicko-ekonomickým systémem, jehož jsou součástí, si zachovávají relativně vysokou úroveň autonomie" (Hodkinson 2002: 32). Právě autonomii, tedy skutečnost, že subkultura funguje do značné míry nezávisle na dominantní společnosti, chápe Hodkinson (2002: 9-33) vedle distinktivnosti, identity a oddanosti (commitment) jako jeden z indikátorů tzv. subkulturní substance. Koncept subkulturní substance představoval Hodkinsonův hlavní argument proti pomíjivosti (post)subkulturních vazeb jakožto jednoho $\mathrm{z}$ hlavních bodů kritiky klasické subkulturní teorie birminghamské školy z per zastánců postsubkulturních studií.

Počátky druhého ze zmiňovaných pólů, tedy konceptualizace subkultury jako „součásti širší společnosti“, lze sledovat k birminghamskému Centru pro současná kulturální studia (CCCS), jehož představitelé v neomarxistické perspektivě, kombinující teorii hegemonie Antonia Gramsciho, ideologie Louise Althussera a sémiotiky Rolanda Barthese, interpretovali britské poválečné subkultury 60 . a 70. let 20. století jako způsob odporu, který odrážel širší třídní boj mezi buržoazií a proletariátem. Subkultury podle nich představovaly strukturní projevy snahy o odlišení se od rodičovské dělnické kultury (charakteristické zaměstnáním bez vyhlídek nebo nezaměstnaností, alkoholismem a domácím násilím) a dominantní buržoazní kultury (zákonodárců a policie, šéfů a učitelů). V optice tř́́dního boje byly britské subkultury nerozlučně spjaty se strukturou společnosti, a tudíž musely být i „analyzovány ve vztahu k dominantní kultuře - celkové dispozici kulturní moci ve společnosti jako celku" (Clarke et al. 1993: 13).

Ačkoliv se postsubkulturní studia od 90 . let 20. století systematicky vymezovala vůči klasické subkulturní teorii birminghamské školy, pohled na subkultury jako „součásti širší společnosti“ si vůči perspektivě birminghamské školy staví jednoznačně kriticky, zároveň v souladu s ní explicitně tvrdí, 
že klubová kultura se objevuje z masové kultury (tj. ve vztahu k dominantní společnosti) jako označení (signifier) kulturních praktik, vkusu a identity.

Stejně tak se této perspektivě blíží i další postsubkulturní autoři, když hovoří o mnohočetnosti, pomíjivosti a fluidnosti (post)subkulturních identit (Muggleton 1998; 2000). Tato neohraničenost, prostupnost a dynamika pak ovšem nutně znamená prolínání i do dominantní společnosti - jinými slovy, i (post)subkulturní identity jsou vyjednávány mezi (post)subkulturami a dominantní společností.

Oběma zmíněným perspektivám je ovšem společný důraz kladený (tu více, tu méně) na vztah subkultury a mainstreamu. ${ }^{4}$ To je však poměrně úzká perspektiva, vezmeme-li v úvahu, že subkultury neexistují pouze ve vztahu s mainstreamem (či dominantní společnostín), ale jsou neustále vystavovány interakcím s dalšími (velmi různorodými) aktéry (a to jak ve smyslu jedinců, tak kolektivit, potažmo dalších entit).

Tento př́stup lze označit do značné míry za typický pro uvažování o subkulturách v českém prostředí ${ }^{6}$ (např. Vaněk 2002; 2010; Pospíšil - Blažek 2010; Oravcová 2011; Slačálek 2011; 2018; Maderová - Jurková - Veselý 2013; Kolářová 2013; Daniel 2016; Novák 2018).

Práce, které tento úzký horizont vztahu subkultury k mainstreamu, respektive dominantní společnosti přesáhly, se vydaly dvěma různými cestami. První z nich je zachycení vztahu subkultury s jiným nemainstreamovým aktérem, respektive dvou subkultur, jak to učinil např́klad Stanley Cohen ve své knize Folk Devils and Moral Panics: Creation of Mods and Rockers (Cohen 2002), v níž pojednává vztah subkultur rockerů a mods, který vyústil v násilné střety obou subkultur. Ovšem hlavním cílem Cohenovy práce nebylo popsání vztahu mezi mods a rockery, ale porozumění vytváření reprezentací obou subkultur ze strany médií a formování vztahu dominantní společnosti k nim. Pojednávaný vztah obou subkultur je tedy spíše vedlejším produktem. Podobným př́kladem, který pojednává vztah subkultury k jinému aktéru, než je dominantní společnost, je studie Johna Garlanda a Paula Hodkinsona „F**king Freak! What the Hell Do You Think You Look Like?": Experiences of Targeted Victimization Among Goths and Developing Notions of Hate Crime

4 Pojem mainstream chápeme jako fluidní reprezentaci neautentické jinakosti, kterou si vytváŕí nositelé subkultur za účelem vymezení sebe sama jako autentických (Muggleton - Weinzierl 2003). Viz také dále.

5 Pojem dominantní společnost budeme užívat k označení kolektivity v durkheimovském slova smyslu. Dominantní společnost může být reprezentována mainstreamem jakožto sociálním konstruktem (viz výše).

6 Nicméně je třeba zmínit, že někteří z autorů vztah s mainstreamem záměrně netematizují a zkoumané jevy nahlížejí jako světy samy pro sebe, např. skrze koncept soundscapes (Jurková 2013). 
(Garland - Hodkinson 2014), která se věnuje vztahu mezi gothiky (goths) a chavs ${ }^{7}$ na pozadí incidentu, jenž se odehrál v roce 2007 v Manchesteru, při němž byla napadena a usmrcena gothička Sophie Lancaster. I v př́ípadě této studie je vztah mezi gothiky a chavs spíše prostředkem rekonceptualizace zločinu z nenávisti (hate crime), než předmětem analýzy, nicméně autoři věnují mimo jiné pozornost také tomu, jak zmíněný incident ovlivnil sebenahlížení gothiků a jejich subkulturní praktiky. A konečně je možné zmínit i práci Hilary Pilkingtonové, Eleny Omelchenkové a Albiny Garifzianové Russia's Skinheads: Exploring and Rethinking Subcultural Lives (Pilkington Omel'chenko - Garifzianova 2010), v níž autorky prostřednictvím reflexe ruských neonacistických skinheads konceptualizují napjatý vztah s neruskými gastarbeitery, zejména z oblasti Kavkazu.

$\mathrm{V}$ českém prostředí tuto perspektivu zohledňuje např́klad Michaela Pixová (2011) ve vztahu punks k emařům. Specificky ji pak pojal Bob Kuř́k (2018), když punk vztahuje k reflexi osoby Václava Havla.

Druhou cestou překonání horizontu vztahu mainstreamu a subkultury je zaměřit se na vztahy mezi různými způsoby ustanovování (enactment) jedné subkultury. Za př́klad může posloužit studie J. Patricka Williamse Authentic Identities. Straightedge Subculture, Music, and the Internet (Williams 2006), v níž autor konceptualizuje vztah mezi dvěma scénami ${ }^{8}$ straight edge (scénou online a scénou tváří v tvář), přičemž jeho hlavním záměrem je však ukázat, jak internet proměňuje vnímání autenticity a s ní i subkulturní praktiky. Podobně lze uvést práci Dunji Brillové Goth Culture: Gender, Sexuality and Style (Brill 2008), v níž jsou analyzovány rozdílné způsoby, jakými gothickou subkulturu ustanovují muži a jakými ženy. Přestože zkoumání genderu takovouto vztahovost vyžaduje ze své podstaty, představuje práce Brillové ukázkový př́klad pojednání vztahů mezi různými způsoby ustanovování konkrétní subkultury. Posledním a vpravdě nejilustrativnějším př́kladem budiž studie Simone Tosoniho Of goths and salmons: A practice-based exploration of subcultural enactments in 1980s Milan (Tosoni 2017), analyzující vzájemné vztahy mezi třemi různými scénami gothiků v italském Miláně 80. let, z nichž každá ustanovuje gothickou subkulturu specifickým způsobem.

Tato perspektiva je $\mathrm{v}$ českém prostředí nejčastěji aplikována $\mathrm{v}$ př́ípadě studií subkultury skinheads, jejíž různá ustanovování k pojednání vzájemných

7 Chavs je hanlivé označení pro chudou, marginalizovanou a znevýhodněnou bílou dělnickou mládež v současné Velké Británii (Garland - Chakraborti Hardy 2015).

8 Scénu, resp. subkulturní scénu, chápeme jako sít aktérů, které pojí společný vkus, sdílený prostor a alespoň tušený pocit společné identity (srov. Williams 2006) 
vztahů v podstatě vybízejí (Stejskalová 2011; Smolík 2015; Charvát 2017; 2018). Objevuje se však také v př́padě punku, respektive hardcore punku (Kumová 2018) či v pojednání genderových vztahů v punkové a hip hopové subkultuře (Kolářová - Oravcová 2018). Všechny zmiňované studie, at již zvolily jakoukoliv cestu, se pokusily překonat úzký dialektický vztah mezi subkulturou a mainstreamem, respektive dominantní společností, tím, že do hry vztáhly další aktéry, at již ze vně (další subkultury či nemainstreamové aktéry) či zevnitř (různé způsoby ustanovování subkultury). Právě syntézu obou cest a jejich systematizování považujeme za cestu, kterou by se některé práce subkulturních studií mohly dále ubírat.

Tzv. relační perspektiva, kterou nabízíme v této studii, se tedy snaží o jistou syntézu těchto př́stupů, nicméně domníváme se, že je více než jejich souborem. Pokusíme se ji totiž obohatit o teoretické zázemí, které nám umožní zdůraznit ustanovování subkultury v kontextu vztahů s různými aktéry a/či entitami. V následující kapitole stručně nastíníme povahu tohoto teoretického zázemí, tedy aplikaci symbolického interakcionismu na teorie subkultur, soudobé teorie identity a alterity a konceptualizaci tzv. mainstreamového Jiného.

\section{Inspirační zdroje relační perspektivy studia subkultur}

Prvním z inspiračních zdrojů našeho relačního přístupu je symbolický interakcionismus, jak jej s ohledem na subkultury rozpracovali Gary Alan Fine a Sheryll Kleinmanová (Fine - Kleinman 1979) a jak jej aplikuje např́klad Patrick Williams (Williams - Copes 2005; Williams 2011).

V perspektivě symbolického interakcionismu není subkultura synonymem subsociety (tedy označením části populace), ale souborem významů přikládaných konkrétním idejím, materiálním objektům a praktikám, které jsou skrze interakci sdílené v rámci sociálních sítí (Fine - Kleinman 1979: 17; Williams 2011: 39). Toto sdílení se však neděje pouze v rámci sítě subkulturní (čili v rámci scény), ale přesahuje její hranice skrze tzv. komunikační propojení (communication interlocks), tedy skrze průniky mezi různými sítěmi konkrétních jedinců. Koncept komunikačních propojení tak zdůrazňuje myšlenku, že aktéři činní v subkulturách nejsou omezeni na komunikaci pouze v rámci své subkulturní sítě (resp. scény), ale mohou komunikovat subkulturní významy všemi kanály sociální interakce. Fine a Kleinmanová (1979) tak definují čtyři typy komunikačních propojení, jež chápou jako významné pro subkultury.

První z komunikačních propojení představují idiokultury jakožto „systémy znalostí, víry, chování a zvyků sdílených členy skupiny, kteří jsou ve vzájemné interakci“ (Fine 1979: 734). Jedná se tedy o lokální (a v př́padě 
zapojení digitálního rozhraní internetu i translokální) sítě relativně malého rozsahu. Typickým př́kladem může být soundsystém ve freeteknu, graffiti crew, společně squatující punks nebo skinheads scházející se ve stejné hospodě. Každá idiokultura je dle Finea a Kleinmanové do jisté míry specifická, přičemž je to právě jejich konglomerát, který na obecnější úrovni konstituuje subkulturu. Nositelé 9 subkultur však nejsou propojeni pouze do sítě s ostatními nositeli dané subkultury, ale jsou zapojeni i do sítí dalších, např́klad příbuzenské, spolužáků, sousedů či známých. Tyto tzv. slabé vazby (Granovetter 1973), tj. vazby udržované instrumentálně v určitém prostředí, představují druhé komunikační propojení, skrze něž dochází k šiřrení významů, a to zcela mimo hranice dané subkultury. Třetí komunikační propojení představují jedinci či skupiny s významným postavením v dané subkultuře, tedy jedinci disponující vysokým subkulturním kapitálem (Thornton 1996; 1997). Právě díky němu tito jedinci šíŕí (at již záměrně či neuvědoměle) vlastní idiokultury mezi idiokultury další. Poslední komunikační propojení představují média, at již subkulturní jako fanziny, webziny, blogy, diskusní fóra či uzavřené skupiny na společenských webových systémech jako je Facebook, jimiž se subkultura šśř́ mezi svými nositeli, nebo ta mainstreamová. Právě mainstreamová média šiří reprezentace subkultury (často ale velmi odlišné od těch produkovaných médii subkulturními) mezi členy dominantní společnosti.

Symbolický interakcionismus tedy zdůrazňuje existenci multiplicitních vztahů subkultur s dalšími entitami, nikoliv pouze jejich vztah s dominantní společností. Jeho koncept komunikačních propojení pak pomáhá vysvětlit nejen způsob, jak se povědomí o subkultuře šírí mainstreamem, ale také, jak nové podněty, ideje a hodnoty vstupují do subkultur.

Pokud přijmeme perspektivu jedince vtaženého do sítě vztahů různých aktérů a entit, $v$ jejichž rámci a jejichž prostřednictvím komunikuje subkulturní významy, je na místě se ptát, jak a prostřednictvím čeho se toto vyjednávání podílí na uskutečňování subkultury. Přičemž jedním z procesů, který je ve vztahu ke konstrukci subkultury konstitutivní, je vyjednávání subkulturní identity.

Subkulturní identitu, tedy pocitovanou, deklarovanou a praktikovanou př́slušnost ke skupině nositelů té které subkultury, potažmo k souboru významů té které subkultuře přikládaných, uvažujeme jako „konstruovanou a opakovaně přehrávanou každodenním jednáním, oděvem, zdobením a dalšími kulturními praktikami“" (Evans 1997: 181, podle Muggleton - Weinzierl 2003). V souladu se sociálním konstruktivismem tedy (sub-

9 Jelikož chápeme subkultury jako systémy významů a praktik, nikoliv konglomerát aktérů, nemůžeme hovořit o členech subkultur. 
kulturní) identitu uvažujeme jako situační, relační, kontextualizovanou a vyjednávanou (Brubaker - Cooper 2000; Eriksen 2007; Bottero 2010 aj.), a to vyjednávanou v sítích aktérů a vztahů. Jako inspirativní se nám jeví poststrukturaliské sociálněvědní př́istupy (v sociokulturní antropologii v tomto ohledu navazující na tzv. postkoloniální obrat), které tematizují proces vyjednávání sociálních identit ve vztahu k Jinému, tedy jako dialektický vztah identity a alterity (Riable 1998: 11, podle Řezníková 2014: 241).

V návaznosti mj. na Foucaultův $(1994 ; 2002)$ rád diskurzu a Saidovu (2008) analýzu konstrukce Orientu jako diskurzivního celku, vůči němuž se evropská kultura vymezovala a tak „získávala sílu a identitu“ (Said 2008: 14), upozorňuje Spivak (1989) na evropocentrickou konstrukci reprezentace subalterního (podřadného) Jiného.

Ačkoliv se poststrukturální a postkoloniální studia v konceptualizaci dialektického vztahu identity a alterity zaměřují především na otázku moci a nerovností, v souvislosti s námi uvažovaným relačním př́stupem je z těchto teorií zásadní důraz na konstrukci a performanci identity „v polarizaci mezi vlastním a cizím“ (Řezníková 2014: 241), kde to „cizí“, tedy Jiné, je rozuměno jen a pouze prostřednictvím konstrukce jeho sociální reprezentace. Tato uvnitř subkultury vytvářená a sdílená reprezentace Jiného umožňuje vcelku jednoduchý způsob ztotožnění se s „vlastním“, přičemž tyto procesy (konstrukce Jiného a identifikace s „vlastním“) probíhají zároveň, jsou spolu komplementárně svázány.

Oním Jiným může být jak mainstream jakožto reprezentace dominantní společnosti (viz pozn. č. 4 a 5), tak ale i další Jiní, v př́padě subkultur především jiné subkultury či obdobné kolektivity zasahující do sociálního pole dané subkultury jako relevantní.

Naším třetím inspiračním zdrojem se staly některé myšlenky obsažené v postsubkulturních teoriích, ${ }^{10}$ konkrétně teorie ustanovování subkulturní autenticity Davida Muggletona a Rupperta Weinzierla (2003). Muggleton a Weinzierl, s odvoláním na práci Sarah Thorntonové (1996) argumentují, že rozlišení (distinction $\mathrm{v}$ bourdiueovském slova smyslu) mezi subkulturou a mainstreamem „se děje vytvořením (...) mainstreamového ,Jiného“ jakožto symbolického bodu, vůči němuž se vlastní vkusy definují jako ,autentickéc“ (Muggleton - Weinzierl 2003: 10). Děje se tak „skrze neustávající proces klasifikování a překlasifikovávání určitých vkusů jako [subkulturně] legitimních" (Muggleton - Weinzierl 2003: 10). Subkulturní identita je tedy utvářena $\mathrm{v}$ konfrontaci s konstrukcí mainstreamového Jiného, vůči němuž

10 Uvědomujeme si, že postsubkulturní teorie představují relativně neucelený soubor rozmanitých konceptů, který v podstatě pojí pouze kritika klasické subkulturní teorie birminghamské školy. Základní přehled postsubkulturních teorií viz (Muggleton - Weinzierl 2003; Bennett 2011). 
se vlastní identita definuje jako autentická, přičemž autenticitu můžeme $\mathrm{v}$ tomto ohledu chápat jako produkt kumulace a adekvátní manifestace subkulturního kapitálu skrze subkulturní styl, ideologii a praktiky. Hranice mezi autentickou subkulturou a neautentickým mainstreamem přitom není pevná, ale neustále se ustanovuje skrze každodenní činnosti jak nositelů subkultury, tak těch, jež jsou definováni jako Jiní. Jiným přitom nemusí být pouze zástupce mainstreamu, ale i nositel (vlastní) subkultury v př́ipadě, že jeho styl, ideologie nebo praktiky jsou označeny jako neautentické (Thornton 1996), respektive pozérské. Hranice mezi subkulturou a mainstreamem tedy existuje tam, kde se (někteří) aktéři kolektivně shodnou, že taková hranice existuje (což samozřejmě může být u různých aktérů různé). Právě existence hranic mezi různými sociálními sítěmi, diskurzy a praktikami a zejména procesy jejich utváření se ukazují jako významně vypovídající o charakteru subkultur.

Máme-li na tomto místě shrnout, jak konkrétně tyto inspirační zdroje přispěly $\mathrm{k}$ formulaci relační perspektivy, můžeme konstatovat, že ze symbolického interakcionismu čerpáme důraz kladený na mnohost aktérů, s nimiž nositelé subkultur interagují, a důležitost těchto interakcí. Subkulturní identitu jednotlivých aktérů přitom chápeme pod vlivem současných teorií sociálních identit jako intersubjektivně vyjednávanou v rámci těchto interakcí. Vztahy mezi subkulturami a všemi relevantními aktéry pak nahlížíme skrze prizma teorie alterity v dichotomii My versus Oni, přičemž konstrukci hranic mezi těmito kategoriemi pak na základě postsubkulturních teorií chápeme jako ustanovující se skrze neustálé intersubjektivní vyjednávání autenticity, respektive její absence.

\section{Relační perspektiva jako př́stup ke studiu subkultur}

Jak jsme zmiňovali již v úvodu a jak ostatně napovídá i sám název, relační perspektiva zdůrazňuje jako základ porozumění subkulturám vztahy mezi různými aktéry, či přesněji vztahy nositelů subkultury k různým dalším aktérům/entitám. Vychází z předpokladu, že subkulturní identita jakožto identita sociální je primárně konstruována ve vztahu k Jiným. To se děje skrze ustanovování subjektivně či přesněji intersubjektivně konstruovaných hranic mezi nositeli subkultury a různými Jinými (My vs. Oni), vůči nimž se nositelé subkultury vymezují jako autentičtí (mainstream a pozérí, resp. jiné formy ustanovování subkultury) či prostě odlišní (obvykle jiné subkultury a nemainstreamová uskupení). Prostředkem tohoto vymezení však není sama kolektivita či její personifikace v podobě jednotlivce, ale její reprezentace, již si jednotliví nositelé subkultury vytvářejí, v interakcích sdílejí (a samozřejmě vyjednávají) a následně (někdy více, někdy méně) 
internalizují. Konfrontace $M y$ versus $O n i$ je tedy v důsledku konfrontací My versus naše predstava fich.

Ačkoliv se tato konstrukce subkulturní identity může dít v podstatě vůči jakékoliv reprezentaci Jiného, na základě našich empirických výzkumů (viz dále) se domníváme, že je užitečné zaměřit pozornost na konstrukci Jiného primárně ve třech základních rovinách či oblastech: mainstreamu jakožto reprezentaci dominantní společnosti; jiných subkultur či jiných nemainstreamových uskupení; a různých způsobů ustanovování vlastní subkultury.

Proč právě tyto tři roviny?

Jelikož se subkultury ustanovují primárně jako antiteze mainstreamu/ dominantní společnosti (Williams 2011: 3), je pro uchopení subkulturní identity nezbytné porozumění toho, co samy považují za mainstream. Ostatně, jak poznamenává Polsky (2005: 70) v kritice kriminologických př́stupů, subkultury je třeba přestat chápat jako problém, s nímž se společnost musí vypořádat, ale pokusit se tento pohled obrátit - na společnost nahlížet jako na problém, s nímž se nějakým způsobem vypořádávají subkultury.

Porozumění vztahům mezi různými způsoby ustanovování dané subkultury zase vyjevuje, jak je subkulturní identita konstruována v návaznosti na různé formy subkulturního kapitálu (kumulovaného na základě manifestace subkulturní ideologie, stylu a praktik), jako ukazatele autenticity. Na této rovině tak můžeme sledovat, jak se vůči sobě vztahují jednotlivé způsoby ustanovování a jak ve vzájemném vztahu konceptualizují pozérství.

A konečně zaměření na jiné subkultury, respektive jiná nemainstreamová uskupení, které figurují v praktikách či diskurzech dané subkultury, vychází z empirické zkušenosti našich dvou zmiňovaných výzkumů. Jak ostatně ukážeme následně, právě vymezení se vůči jiné subkultuře může v některých př́padech představovat primární způsob konstrukce subkulturní identity.

\section{Studium subkultur $\mathbf{v}$ diachronní relační perspektivě}

Dynamika proměn povahy subkultur ve vztahu ke vnějším aktérům/ entitám se nám začala vyjevovat při výzkumu počátků punkové subkultury v českém prostoru. Čím dál zřetelněji se při analýze dat začalo ukazovat, že narativy někdejších aktérů punkové subkultury jsou protkány odkazy na řadu významných Jiných, přičemž právě ve vztahu k nim byla vysvětlována a osvětlována podoba rané punkové scény. Zaměřili jsme tedy svoji pozornost tímto směrem mj. i prostřednictvím výzkumu našich studentů (Klozarová 2004; Dvořák 2006; Novotný 2011; Šarochová 2011), jimiž vytvořená data a některé jejich interpretace v kvalifikačních pracích významně přispěly $\mathrm{k}$ formulaci námi publiko- 
vaných závěrů (Novotná - Dvořák 2008; Novotná - Heřmanský 2012; 2015; Novotná 2013).

Při diachronním studiu proměn punkové subkultury se jako významní Jiní vynořily jednak různé podoby mainstreamu jako reprezentace dominantní společnosti, jednak reprezentace jiných subkultur (významně skinheads, později freetekna, hip hopu či ema) a v neposlední řadě i reprezentace subkultury, s níž se sami identifikovali. Byt' jsme naše texty formulovali především jako analýzu významu vzájemného vztahu mezi punks a skinheads na povahu těchto subkulturních formací, je z nich zřetelné, že mnohem spíše jde o provázanou sít vztahů, v níž figurují všichni uvedení aktéŕi/entity a kde právě aktuální vzájemná konstelace všech těchto aktérů, respektive reprezentací všech těchto aktérů vytváří rámce pro formulaci subkulturních identit a tedy ustanovování subkultur jako takových.

Ustanovování a etablování punkové subkultury v českém prostředí v 80 . letech 20. století bylo vyjednáváno ve vztahu ke konstruktu punku jako stylovému ${ }^{11}$ vymezení se vůči dominantní společnosti. Ta na objevující se praxe punkového subkulturního stylu reagovala konstrukcí reprezentace punku jakožto ideologických oponentů komunistického režimu v praxi socialistického zř́zení, čímž jak diskurzivním tlakem na aktéry rodící se punkové subkultury, tak i konkrétními represivními praxemi de facto zapřícinila konstrukci reprezentace sebe sama jako klíčového ideologického nepř́tele. O několik let později se v českém prostoru etablující skinheadská subkultura pracuje s týmiž reprezentacemi. Tedy reprezentací mainstreamu jako ideologického nepř́tele a reprezentací skinheadské subkultury jako stylu, s nímž se lze identifikovat.

Se změnou politického režimu a otevřením hranic po roce 1989 se proměňuje jak konstrukt mainstreamu, tak subkultur samých. Dominantní společnost (československá, resp. česká) si subkultur nejprve spíše nevšímá, respektive jejich „existenci“ pouze "glosuje“ a z narativů aktérů mizí i její reprezentace, která je nahrazena vymezováním se vůči konstruktu oné druhé subkultury. Tyto reprezentace jsou ale konstruovány významně i prostřednictvím toho, jak tu kterou subkulturu konstruuje právě diskurz dominantní společnosti. Jinými slovy, tlak diskurzivní formace dobové dominantní společnosti ustanovuje reprezentaci punks jako anarchistů a skinheads jako neonacistů. Tento diskurz Jiného, jímž je ta druhá subkultura, je většinově sdílen uvnitř

11 Máme na mysli subkulturní styl (srov. Hebdige 1979; Brake 1987), v tomto př́padě především kombinaci vizáže, hudebního stylu a některých kontrakulturních symbolů - tedy v souladu s tím, co bylo možné přes „železnou oponu“ číst z toho, jak byl punk uskutečňován v západním světě. 
opačné subkultury a podněcuje praxe, které tento diskurz uvnitř obou subkultur i v obrazu dominantní společnosti posilují a tedy legitimují. Aktuálnímu ustanovování obou subkultur za hranicemi České republiky v zahraničí je přitom uvnitř obou subkultur rozuměno, tj. konstruováno, prostřednictvím sdílené reprezentace extrémních poloh subkulturních ideologií. Pokud jde o reprezentaci samotné dominantní společnosti, konstrukt lokálního ideologického nepř́tele (komunistický režim v praxi socialistického zřízení) je po jistém období nezájmu u ideologického jádra punkerů nahrazen reprezentací globálního kapitalistického/neoliberálního nepř́tele, u ideologického jádra skinheads pak konstrukce mainstreamu zůstává spíše v lokálních rámcích a je tvořena zajímavým mixem sounáležitosti s mainstreamovou reprezentací punkerů jako anarchistů, asociálů a fetáků a zároveň opozicí k ideologii multikulturalismu, kterou deklarovala významná část dobové politické reprezentace v České republice.

Zhruba v deseti letech kolem přelomu 80. a 90. let 20. století se tedy významně proměňuje povaha obou subkultur, a to nejen s ohledem na změnu politicko-sociálně-kulturního uspořádání dominantní společnosti, ale i v souvislosti vztahování se k odlišným Jiným. Zatímco před rokem 1989 se tím zásadním Jiným ukáže být lokální mainstream, přinejmenším v první polovině 90 . let 20. století dominuje jako identitotvorný aktér reprezentace konkurenční lokální subkultury. Subkulturní kapitál a tedy měřítko autenticity se $\mathrm{v}$ obou subkulturách posune $\mathrm{z}$ důrazu na subkulturní styl směrem spíše k subkulturní ideologii. V obou případech se ovšem na konstrukci klíčového Jiného podílí také další reprezentace - at' už podob obou subkultur v zahraničí, tak přijetí mainstreamového konstruktu do vlastního diskurzu. Formování vztahu obou subkultur prostřednictvím jejich (negativních) reprezentací v dominantním diskurzu se nicméně ukáže jako natolik silné, že se nadlouho ustálí jako jeden z konstitutivních hraničních prvků obou subkultur, který jsou schopni překročit jen aktéři s hlubokou znalostí jejich vzájemné historie.

Tato lokálně vcelku specificky ustavená situace se proměňuje až v souvislosti s razantnějším vstupem globální (sub)kulturní scény do lokálního kontextu. V důsledku komodifikace subkulturního stylu, aktérství nových subkulturních uskupení na lokální scéně a úpadek zájmu dominantní společnosti o subkultury punks i skinheads ${ }^{12}$ se rozmlžuje i reprezentace Jiného sdílená uvnitř obou subkultur. Zdá se, že v současnosti obě subkultury

12 Dominantní společnost konstruuje své Jiné bud' prostřednictvím „nových“ subkultur - např. freetekno či emo; nebo (a to spíše) nachází své subalterní Jiné v reprezentacích založených na zcela odlišném základě - vedle takřka konstantního konstruktu Romů se objevuje třeba konstrukt „uprchlíků“. 
fungují primárně spíše na principu idiokultur ve smyslu výše zmíněného Fineova (1979) vymezení, tedy jako lokální sítě relativně malého rozsahu, ovšem navíc jako sítě spíše nestabilní, fragmentární, multiplicitní a tedy proměnlivé.

\section{Studium subkultur v synchronní relační perspektivě}

Jak zmiňujeme výše, relační perspektivu jsme koncipovali na základě výzkumu, který měl diachronní povahu. Následně jsme se pokusili aplikovat tento př́stup na výzkum jiné subkultury, tentokrát v perspektivě synchronní. Její náčrt, který prezentujeme níže, tak vychází z dat z etnografického výzkumu emo subkultury s centrem v Praze, který jeden $\mathrm{z}$ autorů tohoto textu provádí od roku 2013. Spíše než o ucelenou interpretaci, jíž by bylo třeba věnovat samostatnou studii, se jedná o nastínění toho, kam mohou směřovat úvahy zakotvené $\mathrm{v}$ relačním př́stupu.

Subkulturní identita emařů/emařek ${ }^{13}$ je ve vztahu k mainstreamu ustanovována jako důsledek morální paniky (Cohen 2002; Goode - Ben-Yehuda 2009; syntetizující přehled viz Thompson 1998), která proběhla v českých médiích v roce 2008 (Heřmanský 2013) a jež zobrazovala emaře jako osoby se sklony k sebepoškozování a sebevraždám. Ačkoliv panika záhy odezněla, vytvořila určitou „mytologii“" (Thompson 1998: 38), tedy stereotypizující reprezentaci, která je se subkulturou dlouhodobě spojená a je natolik perzistentní, že je velmi nesnadné ji narušit. V jejím důsledku jsou emaři často cílem zesměšňování, opovržení a/nebo nenávisti ze strany tzv. hejtrů,${ }^{14}$ jež se projevuje nejen verbálně, ale také fyzicky (srov. Garland - Hodkinson 2014). To vede emaře na jedné straně $\mathrm{k}$ vytváření strategií, jak toto násilí zvládnout (napřr. využitím technik umožňujících nevnímat verbální útoky či gestikulaci). Na straně druhé se tím subkulturní styl stává symbolem oddanosti subkultuře (srov. Hodkinson 2002) a jako takový nabývá významu jakožto zdroj subkulturního kapitálu.

Zatímco vztah emařů k dominantní společnosti je aktéry reflektován poměrně jednoznačně, vztahy k jiným subkulturám (z nichž jako významné

13 Emařremařka je běžně užívané označení nositelů emo subkultury, pro něž se v angličtině užívá termín emo kids (např. Greenwald 2003; Definis-Gojanović - Gugić - Sutlović 2009; Peters 2010), popř́ípadě emos (např. Overell 2010; Seganti - Smahel 2011). Samotní aktéři však někdy užívají také termín emák/ emačka, popřípadě se označují jako patky, čímž odkazují na distinktivní znak emo subkultury - patku vlasů zakrývající jedno z očí.

14 Termín hejtři ( $\mathrm{z}$ angl. haters) používají emaři k označení kohokoliv, kdo se vůči nim projevuje agresivně, opovržlivě či nenávistně. Jedná se častěji o muže než ženy, ovšem věkové rozpětí zahrnuje celou populaci. 
se ukazují skinheads, coristi ${ }^{15}$ a otaku $\left.{ }^{16}\right)$ takto jednoznačné nejsou. Nabývají podoby od obávaných nepřátel (skinheads), přes možnou alternativu (coristi) až k odmítání na straně jedné a identitní fúzi na straně druhé (otaku). Nahlížení skinheads jako nepřátel se odvíjí od kolektivně sdíleného „mýtu“ skinheadských útoků, jež v emařských narativech stály za útlumem aktivity celé pražské emo scény. Naopak coristi, jejichž styl i hudební preference jsou v mnoha ohledech podobné emařským, představují možnou alternativu, s níž se mohou emaři identifikovat $\mathrm{v}$ př́padě, že se situačně či trvale nechtějí identifikovat s identitou emaře. Na straně jedné se může jednat o strategii úniku před stigmatizací (Link - Phelan 2001) způsobenou morální panikou, např́́klad jako obrany před „útoky“ hejtrů, jelikož coristy morální panika (dosud) nepostihla. Může se však jednat i o obranu před potenciálním odsouzením učitele nebo rodiče (či výzkumníka). Na straně druhé může být přijetí této alternativní identity nástrojem, jak čelit osočením z neautentičnosti, respektive pozérství ze strany jiných emařů. Do značné míry ambivalentní je potom vztah k otaku. Mnoho emařů se totiž zároveň identifikuje s otaku a svou identitu situačně a kontextově přizpůsobuje. Oproti tomu jiní emaři se vůči otaku vymezují negativně s poukazem na to, že jsou otaku údajně intelektuálně málo vyspělí, což se projevuje v konzumpci komiksů a animovaných filmů. Hranice je v tomto př́padě ustanovována na základě konstrukce věku skrze praxe, vymezujíc intelektuálně vyspělé (emaře) od intelektuálně nevyspělých (otaku). Lze tak sledovat napětí mezi emaři, kteří otaku odmítají, a otaku/emaři, kteří se s ním částečně identifikují.

Nicméně nejvýznamnější se z hlediska vyjednávání autenticity ukazují vztahy mezi různými podobami ustanovování emo subkultury. Různí aktéři totiž svou emo identitu a autenticitu a v důsledku společně s ní i (ne) autentičnost ostatních konceptualizují různě. Zatímco někteří aktéři ji zakládají na konzumpci hudby, další na manifestaci subkulturního stylu a poslední na internalizaci subkulturní ideologie. Tento nesoulad pak stojí v jádru rozlišování na ty, kteří sdílejí pojetí autenticity a jsou tedy chápáni jako autentičtí, a ty, již je nesdílejí a jsou v důsledku toho označováni jako neautentičtí. Neopominutelnou roli přitom hraje také gender, jelikož ženy

15 Coristi se identifikují s hudebními žánry, jež představují kombinaci metalu a hardcore punku, zejména metalcore a deathcore.

16 Přesnější by bylo hovořit nejen o otaku (fandomu založeném na intenzivním zájmu o japonskou kulturu, zejména populární, i když ne výhradně), ale i cosplayerech (fandomu orientovaném na „hraní rolí" zejména postav z komiksů, ale i filmů či počítačových her) a fanoušcích manga a anime (specifických japonských komiksů a animovaných filmů); nicméně pro jisté zjednodušení budeme (ačkoliv je to trochu zavádějící) užívat zastř̌šující termín otaku. 
jsou jako neautentické označovány mnohem častěji než muži. Za typickou pozérku jsou tak označovány ženy, které svou autenticitu zakládají na manifestaci stylu a zároveň konzumují hudbu, již aktéři-muži, stavějící autenticitu na konzumpci hudby, označují za neemařskou. A vedle toho či spíše současně s tím vstupuje do vyjednávání autenticity i „tělo jako projekt" (Shilling 2003) skrze transformace "těla mainstreamového“ v „tělo emařské“.

Všechny tři roviny (mainstream, jiné subkultury a podoby ustanovování vlastní subkultury) se přitom vzájemně ovlivňují a prolínají. Ustanovování „emařského těla“ se dotýká otázek sebepoškozování, na němž byla založena morální panika. Jednání hejtrů se dotýká praktik spojených se subkulturním stylem a společně mohou ustanovovat transformaci emo identity v identitu coristů. A v tomto „labyrintu“ reprezentací, konceptualizací, označování a ustanovování, mezi ideologií, stylem a praktikami, na pozadí sympatií a antipatií jednotlivých aktérů, dochází k vyjednávání emo identit.

\section{Závěrem}

Domníváme se, že právě zachycení onoho „labyrintu“ reprezentací a praxí je tím, co umožňuje uchopit subkultury nereduktivně a tedy ve všech jejich možných podobách. Byt' se pojetí relačního př́stupu v obou námi uvedených př́padech poněkud liší (což je dáno jak odlišnými cíli výzkumu v souvislosti s diachronním vs. synchronním př́stupem, tak i odlišným dominantním autorstvím obou těchto výzkumů, nehledě na to, že v prvním př́padě jsme závěry výzkumu již publikovali, zatímco v druhém jsou dosud zpracovány jen dílčí studie), spojuje je důraz na uvažování sledovaného tématu v co možná nejširš̌ích kontextech. Právě relační perspektiva nám umožnila tyto kontexty identifikovat a interpretovat, jak se na ustanovování subkultur podílejí. Zdůraznění diskurzivní povahy vyjednávání subkulturní identity mezi různými sociálními reprezentacemi pak dle našeho soudu umožňuje hlubší pochopení jak jednání jednotlivých aktérů, tak dynamiky povahy subkultur jako takových.

Leden 2019

\section{Bibliografie}

Bennet, Andy. 1999. Subcultures or Neo-Tribes? Rethinking the Relationship between Youth, Style and Musical Taste. Sociology 33, 3: 599-617. Bennet, Andy. 2005. In Defence of Neo-tribes: A Response to Blackman and Hesmondhalgh. Fournal of Youth Studies 8, 2: 255-259. 
Bennet, Andy. 2011. The post-subcultural turn: some reflections 10 years on. Fournal of Youth Studies 14, 5: 493-506.

Blackman, Shane. 2005. Youth Subcultural Theory: A Critical Engagement with the Concept, its Origins and Politics, from the Chicago School to Postmodernism. Fournal of Youth Studies 8, 1: 1-20.

Bottero, Wendy. 2010. Intersubjectivity and Bourdieusian Approaches to "Identity". Cultural Sociology 4, 1: 3-22.

Brake, Michael. 1987. Comparative youth culture: the sociology of youth cultures and youth subcultures in America, Britain and Canada. London: Routledge.

Brill, Dunja. 2008. Goth culture: gender, sexuality and style. Oxford: Berg. Brubaker, Rogers - Cooper, Frederick. 2000. Beyond "identity". Theory and Society 29, 1: 1-47.

Clarke, John et al. 1993. Subcultures, Cultures, and Class. In: Hall, Stuart - Jefferson, Tony (eds.): Resistance through rituals: youth subcultures in post-war Britain. London - New York: Routledge: 9-74.

Cohen, Albert K. 1997. A General Theory of Subcultures. In: Gelder, Ken - Thornton, Sarah (eds.): The Subcultures Reader. London - New York: Routledge: $44-54$.

Cohen, Stanley. 2002 ${ }^{3}$. Folk Devils and Moral Panics: Creation of Mods and Rockers. London: Taylor \& Francis.

Daniel, Ondřej. 2016. Kultura svépomocí. Ekonomické a politické rozmèry v českém subkulturním prostředí pozdního státního socialismu a postsocialismu. Praha: Filozofická fakulta Univerzity Karlovy.

Definis-Gojanović, Marija - Gugić, Dijana - Sutlović, Davorka. 2009. Suicide and Emo Youth Subculture - A Case Analysis. Collegium Antropologicum 33, supplement 2, 2: 173-175.

Dvořák, Jiř́. 2006. Vývoj vzájemného vztahu punkové a skinheadské subkultury od 80. let 20. století do současnosti na území Liberecka a Jablonecka. Bakalářská práce. Praha: Univerzita Karlova, Fakulta humanitních studií. Eriksen, Thomas Hylland. 2007. Antropologie multikulturních společností. Rozumět identitě. Praha: Triton.

Evans, Caroline. 1997. Dreams That Only Money Can Buy... Or, The Shy Tribe In Flight from Discourse. Fashion Theory 1, 2: 169-188.

Fine, Gary Alan. 1979. Small Groups and Culture Creation: The Idioculture of Little League Baseball Teams. American Sociological Review 44, 5: 733-745.

Fine, Gary Alan - Kleinman, Sherryl. 1979. Rethinking Subculture: An Interactionist Analysis. The American fournal of Sociology 85, 1: 1-20.

Fischer, Claude S. 1975. Toward a Subcultural Theory of Urbanism. The American Fournal of Sociology 80, 6: 1319-1341. 
Foucault, Michel. 1994. Diskurs, autor, genealogie. Praha: Svoboda.

Foucault, Michel. 2002. Archeologie vědění. Praha: Herrmann \& synové.

Garland, Jon - Hodkinson, Paul. 2014. " $F^{* *}$ king Freak! What the Hell Do You Think You Look Like?": Experiences of Targeted Victimization Among Goths and Developing Notions of Hate Crime. British Journal of Criminology 54, 4: 613-631.

Garland, Jon - Chakraborti, Neil - Hardy, Stevie-Jade. 2015. "It Felt Like a Little War": Reflections on Violence against Alternative Subcultures. Sociology 49, 6: 1065-1080.

Goode, Erich - Ben-Yehuda, Nachman. 2009². Moral panics: the social construction of deviance. Chichester - Malden: Wiley-Blackwell.

Granovetter, Mark S. 1973. The strength of weak ties. American journal of sociology 78, 6: 1360-1380.

Greenwald, Andy. 2003. Nothing feels good: punk rock, teenagers, and emo. New York: St. Martin's Griffin.

Hebdige, Dick. 1979. Subculture: the meaning of style. London: Methuen.

Heřmanský, Martin. 2013. Emoce, žiletky a sebevraždy. Démonizace emo subkultury a morální panika v českém prostředí. In: Daniel, Ondřej - Kavka, Tomáš - Machek, Jakub (eds.): Populární kultura v českém prostoru. Praha: Karolinum: 262-273.

Hesmondhalgh, David. 2005. Subcultures, Scenes or Tribes? None of the Above. Fournal of Youth Studies 8, 1: 21-40.

Hodkinson, Paul. 2002. Goth: identity, style, and subculture. Oxford - New York: Berg.

Charvát, Jan. 2017. Boots and braces don't make me racist: Antiracist skinheads in the Czech Republic'. In: Guerra, Paula - Moreira, Tânia (eds.): Keep it Simple, Make it Fast! An approach to underground music scenes (vol. 3). Porto: Universidade do Porto, Faculdade de Letras: $39-48$.

Charvát, Jan. 2018. Skinheads: permanentní souboj o jméno. In: Charvát, Jan - Kuř́k, Bob (eds.): „Mikrofon je naše bomba." Politika a hudební subkultury mládeže v postsocialistickém Česku. Praha: Togga: 61-110.

Jurková, Zuzana a kol. 2013. Pražské hudební světy. Praha: Karolinum.

Klozarová, Kristýna. 2004. Vizuální atributy punkové subkultury v Československu, respektive v České republice a na Slovensku v 80. a 90. letech 20. století. Bakalářská práce. Praha: Univerzita Karlova, Fakulta humanitních studií.

Kolářová, Marta. 2013. Hudební subkultury mládeže v současné ČR - postsubkulturní či postsocialistické? In: Daniel, Ondřej - Kavka, Tomáš - Machek, Jakub (eds.): Populární kultura v českém prostoru. Praha: Karolinum: 232-248. 
Kolářová, Marta - Oravcová, Anna. 2018. Gender a subkultury: prosazování žen v punku a hip hopu. In: Charvát, Jan - Kuř́k, Bob (eds.): „Mikrofon je naše bomba." Politika a hudební subkultury mládeže v postsocialistickém Česku. Praha: Togga: 301-342.

Kumová, Petra. 2018. DO IT YOURSELF TOGETHER. In: Charvát, Jan - Kuř́k, Bob (eds.): „Mikrofon je naše bomba. "Politika a hudební subkultury mládeže v postsocialistickém Česku. Praha: Togga: 111-160.

Kuř́k, Bob. 2018. Člověk-chyba z Vraha: existenciální revolta punkem v čase „mrtvých havlü“. In: Charvát, Jan - Kuř́k, Bob (eds.): „Mikrofon je naše bomba. "Politika a hudební subkultury mládeže v postsocialistickém Česku. Praha: Togga: 161-210.

Link, Bruce G. - Phelan, Jo C. 2001. Conceptualizing Stigma. Annual Review of Sociology 27, 1: 363-385.

Maderová, Blanka - Jurková, Zuzana - Veselý, Karel. 2013. Dotknout se svèta. Česká hudební alternativa 1968-2013 /To touch the world. Czech music alternative 1968-2013. Praha: FHS UK.

Muggleton, David. 1998. The Post-subculturalist. In: Redhead, Steve (ed.): The clubcultures reader: readings in popular cultural studies. Oxford: Blackwell: 167-185.

Muggleton, David. 2000. Inside subculture: the postmodern meaning of style. Oxford: Berg.

Muggleton, David - Weinzierl, Rupert. 2003. What is "Post-subcultural Studies" Anyway? In: Muggleton, David - Weinzierl, Rupert (eds.): The post-subcultures reader. Oxford - New York: Berg: 3-23.

Novák, Arnošt. 2018. Obsad' a žij: squatting a politika každodennosti v Praze. In: Charvát, Jan - Kuř́lk, Bob (eds.): „Mikrofon je naše bomba." Politika a hudební subkultury mládeže v postsocialistickém Česku. Praha: Togga: 211-264.

Novotná, Hedvika. 2013. Punks and skins united? Souvislosti proměn vztahů punkové a skinheadské subkultury v Československu, resp. v České republice. In: Daniel, Ondřej - Kavka, Tomáš - Machek, Jakub (eds.): Populární kultura v českém prostoru. Praha: Karolinum: 249-261.

Novotná, Hedvika - Dvořák, Jiř́. 2008. Punks vs. Skinheads - Historie jednoho vztahu. In: Bittnerová, Dana - Heřmanský, Martin (eds.): Kultura českého prostoru, prostor české kultury. Praha: Ermat: 261-288. Novotná, Hedvika - Heřmanský, Martin. 2012. An Ambivalent Union: Subcultural Style and Ideology in the Relationship of Punks and Skinheads in the Former Czechoslovakia and Present-day Czech Republic. United Academics fournal of Social Sciences 2, 12: 72-88.

Novotná, Hedvika - Heřmanský, Martin. 2015. Shared enemies, shared friends: the relational character of subcultural ideology in the case of 
Czech punks and skinheads. In: Fight back: punk, politics and resistance. Manchester: Manchester University Press: 170-185.

Novotný, Tomáš. 2011. S.H.A.R.P. - Skinheadi proti rasovým predsudkům. Př́ḱlad současné Prahy. Bakalářská práce. Praha: Univerzita Karlova, Fakulta humanitních studií.

Oravcová, Anna. 2011. Underground českého hip hopu. In: Kolářová, Marta (ed.): Revolta stylem. Hudební subkultury mládeže v České republice. Praha: SLON - Sociologický ústav AV ČR: 123-157.

Overell, Rosemary. 2010. Emo online: networks of sociality/networks of exclusion. Perfect Beat 11, 2: 141-162.

Park, Robert Ezra. 1936. Human Ecology. American fournal of Sociology 42, 1: 1-15.

Park, Robert Ezra - Burgess, Ernest Watson. 1921. Introduction to the science of sociology. Chicago: The University of Chicago Press.

Peters, Brian M. 2010. Emo Gay Boys and Subculture: Postpunk Queer Youth and (Re)thinking Images of Masculinity. Fournal of LGBT Youth 7, 2: 129-146.

Pilkington, Hilary - Omel'chenko, Elena - Garifzianova, Al'bina. 2010.

Russia's Skinheads: Exploring and Rethinking Subcultural Lives. London New York: Routledge.

Pixová, Michaela. 2011. Český punk za oponou i před oponou. In: Kolářová, Marta (ed.): Revolta stylem. Hudební subkultury mládeže v České republice. Praha: SLON - Sociologický ústav AV ČR: 45-82.

Polsky, Ned. 2005². Research Method, Morality and Criminology. In: Gelder, Ken (ed.): The subcultures reader. London - New York: Routledge: 60-72. Pospíšil, Filip - Blažek, Petr. 2010. Vratte nám vlasy! Praha: Academia. Riable, Wolfgang. 1988. Alterität und Identität. Zeitschrift für Literaturroissenschaft und Linguistik 110: 7-22.

Řezníková, Lenka. 2014. Identita/alterita. In: Storchová, Lucie (ed.): Koncepty a dějiny. Proměny pojmů v současné historické vědě. Praha: Scriptorium: 233-243.

Said, Edward W. 2008. Orientalismus. Západní koncepce Orientu. Praha a Litomyšl: Paseka.

Šarochová, Jitka. 2011. Pohyb mezi subkulturami. Konstrukce subkulturní identity prostréednictvím biografického vyprávění. Bakalářská práce. Praha: Univerzita Karlova, Fakulta humanitních studií.

Seganti, Francesca Romana - Smahel, David. 2011. Finding the meaning of emo in youths' online social networking: A qualitative study of contemporary Italian emo. First Monday 16, 7.

Shilling, Chris. 2003². The body and social theory. London - Thousand Oaks: SAGE Publications. 
Slačálek, Ondřej. 2011. České freetekno - pohyblivé prostory autonomie?. In: Kolářová, Marta (ed.): Revolta stylem. Hudební subkultury mládeže v České republice. Praha: SLON - Sociologický ústav AV ČR: 83-122.

Slačálek, Ondřej. 2018. Př́běh Czechteku: lze uniknout morální panice? In: Charvát, Jan - Kuř́k, Bob (eds.): „Mikrofon je naše bomba. “Politika a hudební subkultury mládeže v postsocialistickém Česku. Praha: Togga: 265-300.

Smolík, Josef. 2010. Subkultury mládeže. Uvedení do problematiky. Praha: Grada.

Smolík, Josef. 2015. The Skinhead Subculture in the Czech Republic. Kultura-Społeczeństwo-Edukacja 7, 1: 91-103.

Spivak, Gayatri Chakravorti. 1989. Who claims alterity. In: Kruger, Barbara - Mariani, Phil (eds.): Remaking history. Seattle: Bay Press: 269-292.

Stejskalová, Petra. 2011. Subkultura skinheads - Kam až došly těžké boty. In: Kolářová, Marta (ed.): Revolta stylem. Hudební subkultury mládeže v České republice. Praha: SLON - Sociologický ústav AV ČR: 159-199.

Thompson, Kenneth. 1998. Moral panics. London - New York: Routledge.

Thornton, Sarah. 1996. Club cultures: music, media, and subcultural capital. Middletown: Wesleyan University Press.

Thornton, Sarah. 1997. Social Logic of Subcultural Capital. In: Gelder, Ken - Thornton, Sarah (eds.): The Subcultures Reader. London - New York: Routledge: 200-209.

Tosoni, Simone. 2017. Of goths and salmons: A practice-basedeExploration of subcultural enactments in 1980s Milan. In: Guerra, Paula Moreira, Tânia (eds.): Keep it Simple, Make it Fast! An approach to underground music scenes (vol. 3). Porto: Universidade do Porto, Faculdade de Letras: $279-288$.

Vaněk, Miroslav (ed.). 2002. Ostrůvky svobody. Kulturní a občanské aktivity mladé generace v 80. letech v Československu. Praha: Ústav pro soudobé dějiny AV ČR - Votobia.

Vaněk, Miroslav. 2010. Byl to jenom rock'n'roll? Hudební alternativa v komunistickém Československu 1956-1989. Praha: Academia.

Williams, J. Patrick. 2006. Authentic Identities. Straightedge Subculture, Music, and the Internet. Fournal of Contemporary Ethnography 35, 2: 173-200.

Williams, J. Patrick. 2007. Youth-Subcultural Studies: Sociological Traditions and Core Concepts. Sociology Compass 1, 2: 572-593. 
Williams, J. Patrick. 2011. Subcultural theory: traditions and concepts. Cambridge - Malden: Polity Press.

Williams, J. Patrick - Copes, Heith. 2005. "How Edge Are You?"

Constructing Authentic Identities and Subcultural Boundaries in

a Straightedge Internet Forum. Symbolic Interaction 28, 1: 67-89.

Willis, Paul E. 1978. Profane Culture. London - Boston: Taylor \& Francis. 